\title{
Physiological and Cellular Changes of Stored Cryptocarya aschersoniana
}

\author{
Mez. Seeds
}

\author{
Olívia Alvina Oliveira Tonetti ${ }^{1}$ \\ Wilson Vicente Souza Pereira ${ }^{1}$ \\ Anderson Cleiton José ${ }^{1}$ \\ José Marcio Rocha Faria ${ }^{1}$ (1)
}

${ }^{1}$ Universidade Federal de Lavras, Departamento de Ciências Florestais, Laboratório de Sementes Florestais, Lavras, MG, Brasil

\begin{abstract}
Some species of the Lauraceae family produce seeds that are generally sensitive to desiccation, which makes them difficult to store. The objective of this study was to characterize changes in seed quality of C. aschersoniana from two lots, as well in the physiological and cellular aspects during 12 months of storage. Seeds were stored with their original moisture content (MC) or after pre-drying to $35 \% \mathrm{MC}$ in a cold chamber $\left(5^{\circ} \mathrm{C}\right)$ at a relative humidity of $40 \%$. Seeds were sampled and tested at time $0,3,6$ and 12 months of storage regarding to moisture content, germination and ultrastructural features. The seeds were dispersed with dormancy that was overcame by the cold storage condition and the reserves in undried seeds were partly consumed during storage. Both undried and pre-dried seeds remained viable for at least 12 months.
\end{abstract}

Keywords: Lauraceae, seed conservation, storage, ultrastructural analyses.

\section{INTRODUCTION AND OBJECTIVES}

In order to have an efficient storage, the seed moisture content must be low. However, seeds that are sensitive to desiccation, including seeds of many tropical species, need to be kept sufficiently moist for metabolism not to be interrupted (Walters et al., 2001) and for gas exchange to occur. Because of their active metabolism, desiccationsensitive seeds can germinate during storage and, even if there is no sufficient water for germination to complete, their reserves continue to be consumed, leading to a loss of viability (Marcos-Filho, 2005). Storage alternatives that have been proposed for these seeds include the removal of free water, a procedure that helps to maintain seed viability (Walters, 2000; Bonjovani \& Barbedo, 2008), by lowering the metabolic rates, as well as prevent infestations by microorganisms (Lima et al., 2018). In some cases, this partial drying may also improve the seed quality by provoking a moderate stress condition that generates a certain positive response in the seed (Walters, 2000).

The Lauraceae family is one of the most diverse in Brazilian forestry formations, with species frequently being found in the remaining riparian forests in Southeast Brazil. Some species of this family belong to the ecological group clímax (Lorenzi, 1998) and produce seeds irregularly that are generally sensitive to desiccation (Carvalho et al., 2008; Vicente et al., 2016) and, in some cases, with dormancy (Jaganathan et al., 2019). In particular, seeds of Cryptocarya aschersoniana have been reported to be sensitive to desiccation (Carvalho, 2000; Hirano, 2004; Muxfeldt et al., 2012). These seeds are dispersed during the rainy season (Lorenzi, 1998) and often need to be stored, even for short periods, to be sown later in order to synchronize the end of the seedling production cycle with the beginning of the next rainy season. Therefore, the objective of this study was to characterize changes in seed quality of C. aschersoniana, as well in the physiological and cellular aspects during 12 months of storage.

\section{MATERIAL AND METHODS}

\subsection{Characterization of the material}

Ripe (yellow) fruits of C. aschersoniana were collected in Lavras, Minas Gerais state, Brazil, in February, in two different years. The fruits were processed under running water 
and through a sieve until the pulp was completely removed. The dispersal structures were considered to be the "seeds", formed by the seed itself within a woody endocarp. The seeds were spread in a single layer in the open air until the surface water had evaporated. These seeds were considered as "recently harvested".

Some of the seeds were maintained at their initial moisture content. Other seeds were pre-dried until a target moisture content of $35 \%$ was reached. This pre-drying step was performed in drying boxes with silica gel at the bottom, in an air-conditioned room $\left(20^{\circ} \mathrm{C}\right)$. The silica gel was changed whenever the color indicator for humidity (blue) turned pale. The internal condition in the boxes was maintained at $20{ }^{\circ} \mathrm{C}$ with a relative humidity (RH) between $13.5 \%$ and $40 \%$. The $35 \%$ target moisture content was chosen because pilot tests performed in the same laboratory indicated that this level does not cause a significant drop in germination rates, however, below this moisture content, the seeds had an increased risk of loss of viability (data not shown).

Samples of the obtained biological material were taken for the initial physiological characterization tests (moisture content and germination) and image analyses (electronic microscopy), as described below.

\subsection{Moisture content test}

The oven moisture test was performed at $105^{\circ} \mathrm{C}$ for $24 \mathrm{~h}$ (Brasil, 2009), in 4 replications of 5 cut seeds placed in aluminum foil packets. The moisture content was calculated on a wet basis as the average of the 4 repetitions.

\subsection{Germination test}

The germination test was performed in 4 replications of 25 seeds that had been previously washed in $1.0 \%$ sodium hypochlorite for $10 \mathrm{~min}$. Seeds were placed into plastic trays $(27 \times 40 \mathrm{~cm})$ containing autoclaved sand, which were incubated in a Mangelsdorf germinator at $25^{\circ} \mathrm{C}$ under continuous light. Seeds were considered to have germinated when they produced normal seedlings within a 120-day period. At the end of the test, seeds that had not germinated were cut and incubated in a solution of tetrazolium (Vetec, Rio de Janeiro, Brazil) at $0.5 \%, 25^{\circ} \mathrm{C}$, for $24 \mathrm{~h}$. They were considered viable if they stained pink/red in color, indicating respiratory activity in their tissues.

\subsection{Ultrastructural analysis}

The ultrastructure of the samples was analyzed by scanning electron microscopy (SEM). Samples (5 seeds) were prepared according to the following protocol: seeds were cut lengthwise in the area of the embryonic axis. Samples were fixed in a modified Karnovsky solution (2.5\% glutaraldehyde, $0.05 \mathrm{~mol} / \mathrm{L} \mathrm{CaCl}_{2}, 0.001 \mathrm{~mol} / \mathrm{L}$ sodium cacodylate buffer, $\mathrm{pH}$ 7.2) for at least $24 \mathrm{~h}$. Samples were transferred to a cryo-protectant solution (glycerol $30 \% \mathrm{v} / \mathrm{v}$ in water) for $30 \mathrm{~min}$ and sectioned longitudinally in liquid nitrogen using a scalpel blade. The specimens were dehydrated in a gradient acetone series $(1 \times 25 \%, 50 \%, 75 \%$ and $90 \%, 3 \times 100 \%$; $10 \mathrm{~min}$ each), and then transferred to a critical-point dryer (Bal-Tec) to evaporate the acetone without loss of tissue conformation. The samples were placed in stubs lined with aluminum foil, over carbon tape, and submitted to gold-sputtering in a Sputter Coater SCB 050 gold evaporator. Finally, the samples were examined by scanning electron microscopy (SEM) (LEO EVO $40 \mathrm{XVP}$ ). Observations focused on the transition area from the embryonic axis to the cotyledons.

\subsection{Storage}

After the initial tests were completed, samples with the two moisture contents were stored in a cold chamber $\left(5^{\circ} \mathrm{C}\right.$, $40 \% \mathrm{RH}$ ) in semipermeable packages (sealed plastic bags with holes punched in them). The above evaluations were repeated after 3, 6 and 12 months of storage and compared to the results before storage.

\subsection{Data analysis}

All the experiments were set using a completely randomized design. Data had the normality analyzed using the Shapiro Wilk Test, if no normal distribution was observed, those were transformed into arcsin of $\sqrt{ }(x / 100)$. Normal data or those normalized by the transformation were analyzed by ANOVA and Tukey's test at $5 \%$ probability. Those data whose distribution was not normal, even after transformation, were analyzed by Generalized Linear Models (GLM) and if detected significant differences among the variables, the data were compared by Duncan's test at $5 \%$ probability. All analyses were carried using the software $\mathrm{R}$ for Windows (R Core Team, 2020).

\section{RESULTS AND DISCUSSION}

From the initial results (Tables 1, 2 and 3), the average moisture content of seeds collected in year one was $40.6 \%$, and the average percentage of germination was $15 \%$. Seeds harvested in year two showed an average moisture content of $47.0 \%$, and percentage of germination of $6 \%$. After pre-drying, the average moisture content and germination 
were $35.5 \%$ and $9 \%$, respectively, in the first year, and $37.8 \%$ and $9 \%$, respectively, in the second year. The moisture content of the seeds remained stable over 12 months of storage, without significant variation $(\mathrm{p}<0.05)$.

After storage, the percentage of germination increased irrespective of the collection year, with the highest increases being observed after 6 months of storage, remaining stable for up to 12 months for both lots (Figure 1). Slight reduction of moisture by pre-drying did not influence the final percentage of germination $(\mathrm{p}<0.05)$ at time zero (Tables 2 and 3), as already reported for the study species (Hirano, 2004; Muxfeldt et al., 2012) and for recalcitrant seeds of Inga vera (Faria et al., 2004). After 12 months of storage, although there was no effect of pre-drying on final percentage of germination for both lots, seeds from the second year subjected to pre-drying germinated slower than those that were stored wet (Table 3).

Table 1. Variation in moisture content of Cryptocarya aschersoniana seeds during storage. $\mathrm{SD}=\mathrm{Standard}$ Deviation, $\mathrm{CV}=$ coefficient of variation.

\begin{tabular}{ccccccccc}
\multirow{2}{*}{$\begin{array}{c}\text { Collection } \\
\text { year }\end{array}$} & $\begin{array}{c}\text { Storage } \\
\text { condition }\end{array}$ & $\mathbf{0}$ & $\mathbf{3}$ & $\mathbf{6}$ & $\mathbf{1 2}$ & Mean \pm SD & CV (\%) \\
\cline { 3 - 6 } Year 1 & Wet & 40.6 & 40.4 & 40.6 & 39.5 & $40.3 \pm 0.53$ & 4.12 \\
& Pre-drying & 35.5 & 34.9 & 35.4 & 35.8 & $35.4 \pm 0.37$ & 2.87 \\
\multirow{2}{*}{ Year 2 } & Wet & 47.0 & 45.8 & 47.6 & 48.3 & $47.2 \pm 1.06$ & 3.93 \\
& Pre-drying & 37.8 & 36.4 & 35.7 & 38.4 & $37.1 \pm 1.24$ & 6.94 \\
\hline
\end{tabular}
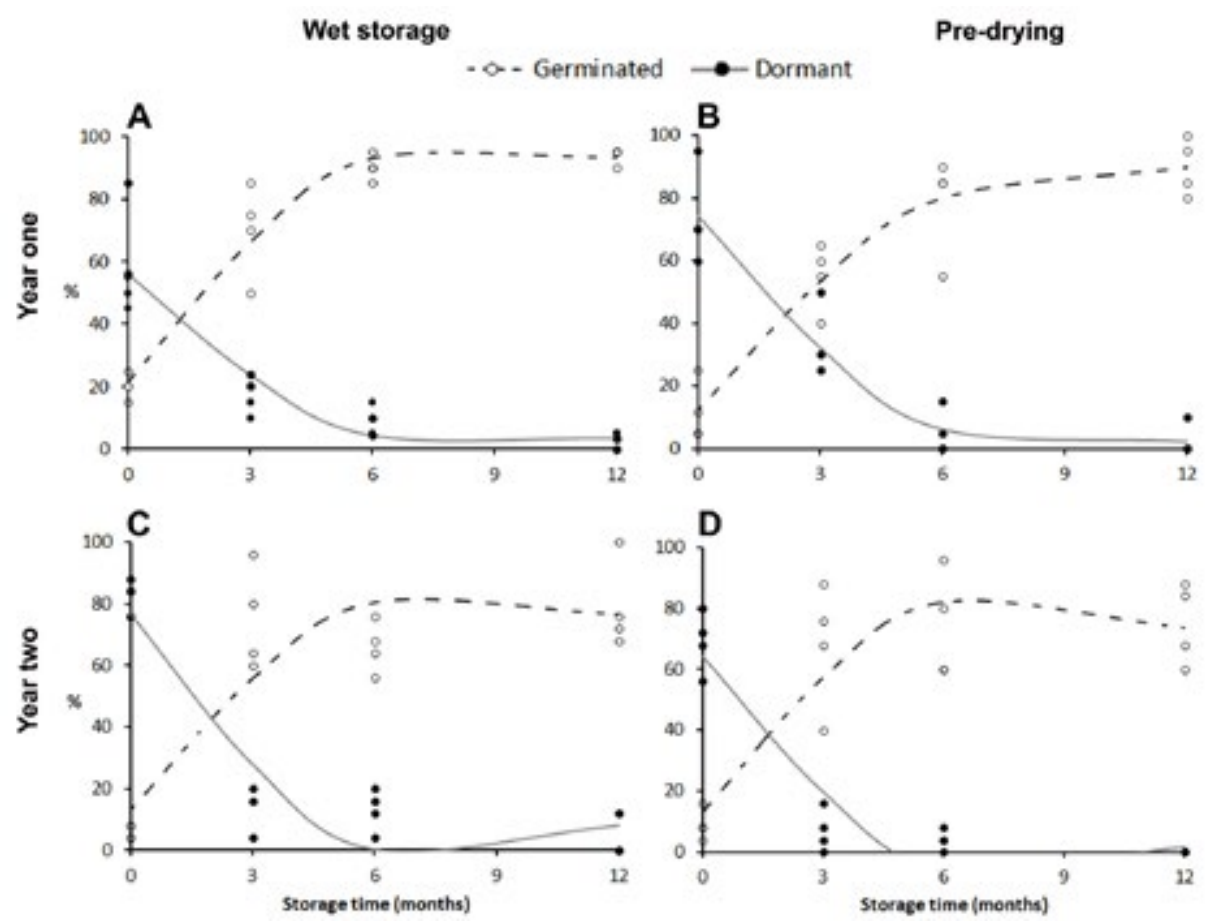

Figure 1. Behaviour of Cryptocarya aschersoniana seeds stored in cold chamber $\left(5^{\circ} \mathrm{C} / 40 \% \mathrm{RH}\right)$ for $0,3,6$ and 12 months. Regression equations and $\mathrm{R}^{2}$ values are as follows: A) Germinated: $\mathrm{y}=21.466+17.839 \mathrm{x}-0.988 \mathrm{x}^{2}\left(\mathrm{R}^{2}=0.9309\right)$; Dormant: $\mathrm{y}=55.9205-12.8201 \mathrm{x}-0.7039 \mathrm{x}^{2}$ $\left(\mathrm{R}^{2}=0.8015\right)$; B) Germinated: $\mathrm{y}=12.2803+16.1061 \mathrm{x}-0.8039 \mathrm{x}^{2}\left(\mathrm{R}^{2}=0.8812\right)$; Dormant: $\mathrm{y}=74.3295-16.7216 \mathrm{x}-0.8933 \mathrm{x}^{2}\left(\mathrm{R}^{2}=0.8812\right)$; C) Germinated: $y=13.2273+17.1288 x-0.9874 x^{2}\left(R^{2}=0.6889\right)$; Dormant: $y=76.645-19.741 x+1.169 x^{2}\left(R^{2}=0.8242\right)$; $\left.D\right) G e r m i n a t e d$ : $y=13.036+17.961 x-1.076 x^{2}\left(R^{2}=0.7247\right) ;$ Dormant: $y=64.227-18.038 x+1.068 x^{2}\left(R^{2}=0.8632\right)$. 
Table 2. Germination of Cryptocarya aschersoniana seeds (first year) after different storage times. $\mathrm{G}=$ Germination; DoS $=$ Dormant seeds; DeS = Dead seeds; MGT = Mean germination time; GSI = Germination speed index.

\begin{tabular}{|c|c|c|c|c|c|c|}
\hline \multirow{2}{*}{$\begin{array}{l}\text { Storage } \\
\text { time } \\
\text { (months) }\end{array}$} & \multirow{2}{*}{$\begin{array}{l}\text { Storage } \\
\text { condition }\end{array}$} & G & DoS & DeS & \multirow{2}{*}{$\begin{array}{l}\text { MGT } \\
\text { (days) }\end{array}$} & \multirow{2}{*}{ GSI } \\
\hline & & & $\%$ & & & \\
\hline \multirow{2}{*}{0} & Wet & $15 \mathrm{a}$ & $59 \mathrm{a}$ & $26 \mathrm{a}$ & $96 \mathrm{a}$ & $0.043 \mathrm{a}$ \\
\hline & Pre-drying & $9 a$ & $74 \mathrm{a}$ & $17 \mathrm{a}$ & $97 \mathrm{a}$ & $0.027 \mathrm{a}$ \\
\hline \multirow{2}{*}{3} & Wet & $70 a$ & $16 \mathrm{a}$ & $14 \mathrm{a}$ & $52 \mathrm{a}$ & $0.287 \mathrm{a}$ \\
\hline & Pre-drying & $55 \mathrm{~b}$ & $34 \mathrm{a}$ & $11 \mathrm{a}$ & $50 a$ & $0.258 \mathrm{a}$ \\
\hline \multirow{2}{*}{6} & Wet & $90 \mathrm{a}$ & $10 \mathrm{a}$ & $0 \mathrm{a}$ & $33 \mathrm{a}$ & $0.643 \mathrm{a}$ \\
\hline & Pre-drying & $79 \mathrm{~b}$ & $5 \mathrm{a}$ & $16 \mathrm{a}$ & $39 a$ & $0.482 \mathrm{~b}$ \\
\hline \multirow{2}{*}{12} & Wet & $93 \mathrm{a}$ & $3 a$ & $4 \mathrm{a}$ & $39 a$ & $0.549 \mathrm{a}$ \\
\hline & Pre-drying & $90 \mathrm{a}$ & $3 \mathrm{a}$ & $7 \mathrm{a}$ & $43 \mathrm{a}$ & $0.509 \mathrm{a}$ \\
\hline
\end{tabular}

Mean values followed by the same letter in the column, within each storage time, do not differ from each other. Data were compared by Duncan at $5 \%$ probability.

The total percentage of germination increased by storing seeds for both years of collection, irrespective of their initial condition (wet or pre-dried), simultaneously to the decrease in the percentage of dormant seeds (Figure 1). Pre-drying the seeds did not have any effect on the percentage of dead seeds throughout the storage time (Tables 2 and 3). It can also be observed that the mean germination time (MGT) decreased, coinciding with increasing values of germinating speed index
(GSI) along the storage time (Figure 2). In other words, the longer the storage time, the faster the germination. These results suggest that the low initial germination was due to some kind of dormancy that was released during storage (Figures 1 and 3). A similar behaviour was found in seeds of Carthamus tinctorius - Asteraceae (Oba et al., 2019) and of other species of Lauraceae (Carvalho, 2000; Carvalho et al., 2008).

Table 3. Germination of Cryptocarya aschersoniana seeds (second year) after different storage times. $\mathrm{G}=$ Germination; DoS $=$ Dormant seeds; DeS $=$ Dead seeds; MGT $=$ Mean germination time; GSI = Germination speed index.

\begin{tabular}{|c|c|c|c|c|c|c|}
\hline \multirow{2}{*}{$\begin{array}{l}\text { Storage } \\
\text { time } \\
\text { (months) }\end{array}$} & \multirow{2}{*}{$\begin{array}{l}\text { Storage } \\
\text { condition }\end{array}$} & G & DoS & DeS & \multirow{2}{*}{$\begin{array}{l}\text { MGT }^{*} \\
\text { (days) }\end{array}$} & \multirow{2}{*}{ GSI $^{*}$} \\
\hline & & & $\%$ & & & \\
\hline \multirow{2}{*}{0} & Wet & $6 \mathrm{a}$ & $83 \mathrm{a}$ & $11 \mathrm{a}$ & $65 a$ & $0.027 \mathrm{a}$ \\
\hline & Pre-drying & $9 \mathrm{a}$ & $69 \mathrm{~b}$ & $22 \mathrm{a}$ & $62 \mathrm{a}$ & $0.049 \mathrm{a}$ \\
\hline \multirow{2}{*}{3} & Wet & $75 \mathrm{a}$ & $11 \mathrm{a}$ & $14 \mathrm{a}$ & $56 a$ & $0.406 \mathrm{a}$ \\
\hline & Pre-drying & $68 \mathrm{~b}$ & $7 a$ & $25 \mathrm{a}$ & $47 \mathrm{a}$ & $0.484 \mathrm{a}$ \\
\hline \multirow[b]{2}{*}{ 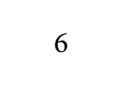 } & Wet & $66 \mathrm{a}$ & $13 \mathrm{a}$ & $21 \mathrm{a}$ & $37 \mathrm{a}$ & $0.685 \mathrm{a}$ \\
\hline & Pre-drying & $74 \mathrm{a}$ & $4 \mathrm{~b}$ & $22 \mathrm{a}$ & $39 a$ & $0.655 \mathrm{a}$ \\
\hline \multirow{2}{*}{12} & Wet & $79 \mathrm{a}$ & $6 \mathrm{a}$ & $15 \mathrm{a}$ & $23 \mathrm{a}$ & $1,130 \mathrm{a}$ \\
\hline & Pre-drying & $75 \mathrm{a}$ & $0 \mathrm{a}$ & $25 \mathrm{a}$ & $38 \mathrm{a}$ & $0.608 \mathrm{~b}$ \\
\hline
\end{tabular}

Mean values followed by the same letter in the column, within each storage time, do not differ from each other. Data were compared by Duncan test at $5 \%$ probability and ${ }^{\star}$ Tukey test at $5 \%$ probability.

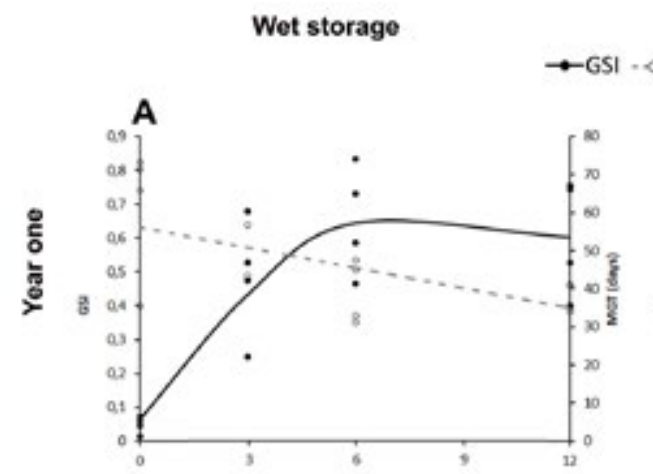

Pre-drying
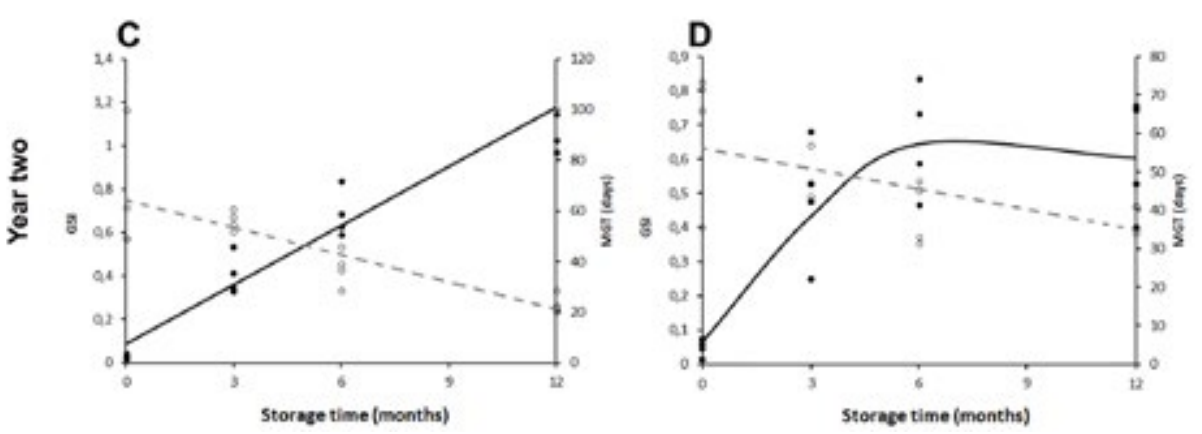

Figure 2. Germination speed index (GSI) and mean germination time (MGT) of Cryptocarya aschersoniana seeds stored in cold chamber $\left(5^{\circ} \mathrm{C} / 40 \% \mathrm{RH}\right)$ for $0,3,6$ and 12 months. Regression equations and $\mathrm{R}^{2}$ values are as follows: A) GSI: $\mathrm{y}=0.013119+0.143699 \mathrm{x}-0.008179 \mathrm{x}^{2}$ $\left(\mathrm{R}^{2}=0.8457\right) ;$ MGT: $\left.\mathrm{y}=96.806-16.770 \mathrm{x}+1.004 \mathrm{x}^{2}\left(\mathrm{R}^{2}=0.9563\right) ; \mathrm{B}\right) \mathrm{GSI}: \mathrm{y}=0.01584+0.10678 \mathrm{x}-0.00545 \mathrm{x}^{2}\left(\mathrm{R}^{2}=0.8412\right)$; MGT: $\left.y=95.4254-15.2399 x+0.9088 x^{2}\left(R^{2}=0.9381\right) ; C\right)$ GSI: $y=0.08773+0.09079 x\left(R^{2}=0.7049\right) ;$ MGT: $y=64.262-3.589 x\left(R^{2}=0.6294\right)$; D) GSI: $y=0.064171+0.148392 x-0.008626 x^{2}\left(R^{2}=0.7049\right)$; MGT: $y=56.137-1.765 x\left(R^{2}=0.3077\right)$. 

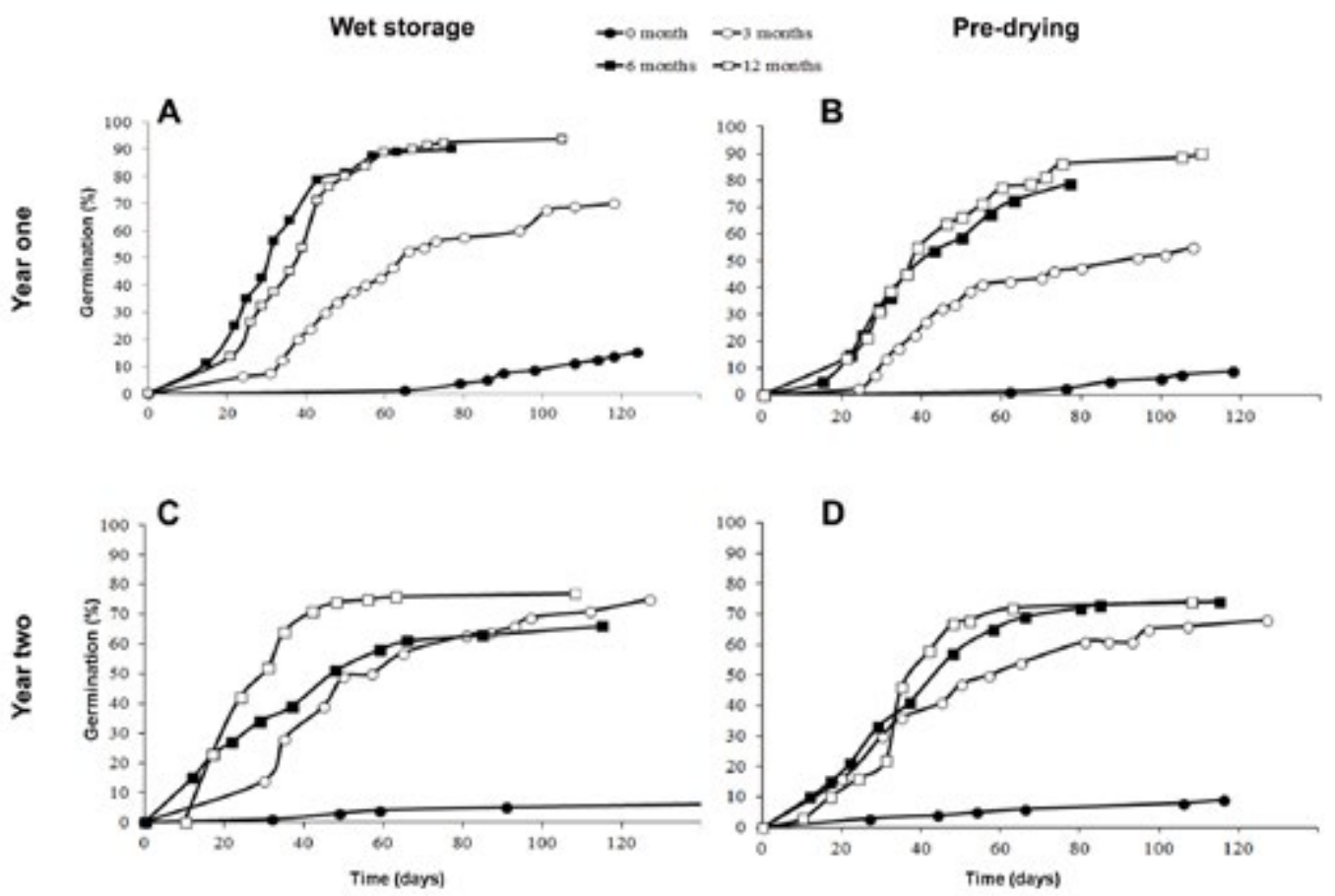

Figure 3. Germination of Cryptocarya aschersoniana seeds stored in cold chamber $\left(5^{\circ} \mathrm{C} / 40 \% \mathrm{RH}\right)$ for $0,3,6$ and 12 months.

C. arshersoniana seeds probably have nondeep physiological dormancy, caused by the presence of the endocarp. According to Baskin and Baskin (2014), covering structures may reduce the rate of imbibition, restrict movement of oxygen to the embryo, mechanically restrict embryo growth and contain germination inhibitors.

This behavior may be related to the ecology of the species, and may reflect its adaptation to naturally occurring conditions. C. aschersoniana is typical of Brazilian subtropical forests and, in lower latitudes, often appears in higher altitude forest (Lorenzi, 1998). Seeds are released at the end of the rainy season (Hirano, 2004) and they need to survive through a cold and dry season and remain dormant until the conditions are favorable for germination and seedling development, as reported by Jaganathan et al. (2019), who described the behaviour of seeds of several Lauraceae species that are dispersed with nondeep physiological dormancy that can be released by cold stratification. Similar adaptations are common in recalcitrant seeds of temperate species, as seen in acorns oak (Pasquini et al., 2011, 2012). These seeds generally disperse in the autumn and must survive through the winter without germinating, which involves a process of dormancy and some strategy to reduce water loss (Pammenter \& Berjak, 2000; Bewley et al., 2013).

Similar results for storing Lauraceae seeds were found for 4 species after 4 months at 4.0 to $10.0^{\circ} \mathrm{C}$ (Hirano, 2004),
Nectandra nitidula after 90 days and Nectandra lanceolata after 180 days of storage in a cold chamber (Carvalho, 2006). Persea pyrifolya and Cryptocarya aschersoniana seeds overcome dormancy when stored moist for 3 months in a cold chamber (Carvalho, 2000). For Quercus ilex, a species taken as a model for recalcitrance and dormancy, storing the seeds in wet sand at $3.0^{\circ} \mathrm{C}$ encouraged germination after 1 month of storage (Pasquini et al., 2011).

The SEM findings (Figure 4) show that there was no damage to the cell structure after 12 months of storage, however, suggest that seeds stored at their original moisture (Figure 4B) had lower reserves of starch granules compared to seeds that were pre-dried before storage (Figure 4D).

To preserve seeds in the long term, their metabolic rates must be reduced. This reduction can be achieved and the germination process impeded by reducing both the amount of free water (Walters, 2000; Walters et al., 2005) and the temperature (Hong \& Ellis, 2002). However, even at reduced temperatures, the metabolism may remain active during storage (Bonjovani \& Barbedo, 2019) and is probably more intense in seeds that had not been predried. Wet storage expose the seeds to a stress condition and, according to Oliveira et al. (2020), when the amount of water available is not enough to complete germination, it may occur a disordinated consumption of reserves, leading to viability loss. 


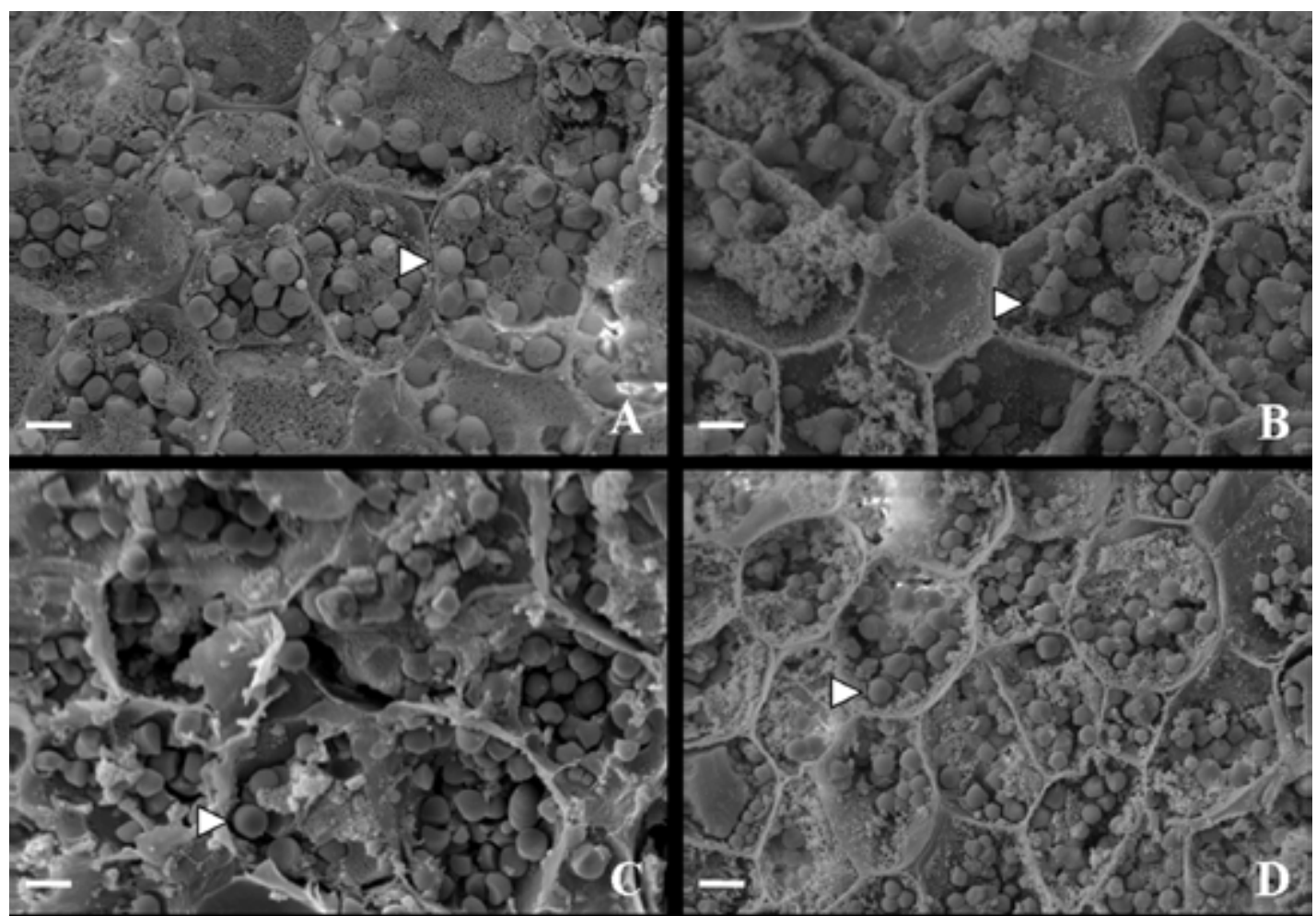

Figure 4. Image of the transition region between the embryonic axes and the cotyledons of Cryptocarya aschersoniana seeds, through scanning electronic microscopy (SEM). A and B = wet storage at zero and 12 months of storage. $\mathrm{C}$ and $\mathrm{D}=$ pre-dried seeds at zero and 12 months of storage. Arrow indicates starch granule. Bar represents $10 \mu \mathrm{m}$.

\section{CONCLUSIONS}

Taken together, the results of this study suggest that C. aschersoniana seeds are released with dormancy and, one way to overcome this dormancy is storing the wet seeds in plastic bags in cold chamber $\left(5^{\circ} \mathrm{C}\right)$ at $40 \% \mathrm{RH}$. Under this storage condition, the viability of the seeds can be kept for at least 12 months, regardless of whether the seeds are stored with their initial moisture content or pre-dried to a moisture content of $35.5 \%$.

Microscopic analyses suggested that C. aschersoniana seeds stored in a cold chamber with their initial moisture partly consume their reserves by metabolism, which may lead to a loss of viability during longer storage periods.

\section{ACKNOWLEDGEMENTS}

A.C.J. and J.M.R.F. thank Conselho Nacional de Desenvolvimento Científico e Tecnológico (CNPq) for the research productivity fellowships (Processes 310976/2018-9 and 311556/2018-3, respectively).

\section{SUBMISSION STATUS}

Received: 04 Aug. 2020

Accepted: 10 Mar. 2021

Associate editor: Natane Miranda (1)

\section{CORRESPONDENCE TO}

\section{José Marcio Faria}

Universidade Federal de Lavras, Laboratório de Sementes Florestais. Campus Universitário, s/n. Cx. Postal 3037, CEP 37200-900, Lavras, MG, Brasil

e-mail: jmfaria@ufla.br

\section{REFERENCES}

Baskin CC, Baskin JM. Seeds: ecology, biogeography, and evolution of dormancy and germination. 2nd ed. San Diego: Elsevier/Academic Press; 2014.

Bewley JD, Black M, Bradford KJ, Hilhorst HWM, Nonogaki H. Seeds: Physiology of development, germination and dormancy. 3rd ed. New York: Springer; 2013.

Bonjovani MR, Barbedo CJ. 2008. Sementes recalcitrantes: intolerantes a baixas temperaturas? Embriões recalcitrantes de Inga vera Willd. subesp. affinis (DC)T.D. Penn. toleram temperatura sub-zero. Revista Brasileira de Botânica 2008; 31(2):345-356.

Bonjovani MR, Barbedo CJ. 2019. Respiration and deterioration of Inga vera ssp. affinis embryos stored at different temperatures. Journal of Seed Science 2018; 41(1):44-53.

Brasil, Ministério da Agricultura, Pecuária e Abastecimento. Regras para Análise de Sementes. Secretaria de Defesa Agropecuária Brasília: MAPA/ACS. 2009. 
Carvalho LR. Classificação fisiológica de sementes de espécies florestais quanto à capacidade de armazenamento [dissertação] Lavras: Universidade Federal de Lavras; 2000.

Carvalho LR. Conservação de sementes de espécies dos gêneros Nectandra, Ocotea e Persea (Lauraceae). [tese] Lavras: Universidade Federal de Lavras; 2006.

Carvalho LR, Davide AC, Silva EAA, Carvalho MLM. Classificação de sementes de espécies florestais dos gêneros Nectandra e Ocotea (Lauraceae) quanto ao comportamento no armazenamento. Revista Brasileira de Sementes 2008; 30(1):1-9.

Faria JMR, van Lammeren AAM, Hilhorst HWM. Desiccation sensitivity and cell cycle aspects in seeds of Inga vera subsp. affinis. Seed Science Research 2004; 14(2):165-178.

Hirano E. Maturação fisiológica, tolerância à dessecação e conservação de sementes de lauráceas da mata de araucária de Santa Catarina. [tese] Curitiba: Universidade Federal do Paraná; 2004.

Hong TD, Ellis RH. Storage. In: Vozzo JA, editor. Tropical tree seed manual. Washington DC: USDA Forest Service; 2002.

Jaganathan GK, Li J, Yang Y, Han Y, Liu B. Complexities in identifying seed storage behavior of hard seed-coated species: a special focus on Lauraceae, Botany Letters 2019; 166(1):1-10.

Lima JME, Oliveira JA, Smirdele OJ, Lousado AVC, Carvalho MLM. Physiological performance of açaí seeds (Euterpe oleraceae Mart.) stored with different moisture content and treated with fungicide. Journal of Seed Science 2018; 40(2):135-145.

Lorenzi H. Árvores brasileiras: manual de identificação e cultivo de plantas arbóreas nativas do Brasil. Nova Odessa: Plantarum; 1998.

Marcos Filho J. Fisiologia de sementes de plantas cultivadas. Piracicaba: Fealq; 2005.

Muxfeldt RE, Faria JMR, Tonetti OAO, Silva EAA. Utilização do teste de raios-X na avaliação dos efeitos da dessecação e infestação em diásporos de canela batalha (Cryptocarya aschersoniana Mez Lauraceae). Cerne 2012; 18(4):654-666.
Oba G, Goneli ALD, Masetto TE, Hartmann-Filho CP, Michels KLLS, Avila JPC. Artificial drying of safflower seeds at different air temperatures: effect on the physiological potential of freshly harvested and stored seeds. Journal of Seed Science 2019; 41(4):397-406.

Oliveira TF, Santos HOS, Carvalho RA, Silva HW, Pires RMO, Carvalho ER. Reserve mobilization in soybean seeds under water restriction after storage. Journal of Seed Science 2020. 42(1):1-8.

Pammenter NW, Berjak P. Evolutionary and ecological aspects of recalcitrant seed biology. Seed Science Research 2000; 10(3):301-306.

Pasquini S, Braidot E, Petrussa E, Vianello A. Effect of different storage conditions in recalcitrant seeds of holm oak (Quercus ilex L.) during germination. Seed Science and Technology 2011; 39(1):165-177.

Pasquini S, Mizzau M, Petrussa E, Braidot E, Patui S, Gorian F et al. Seed storage in polyethylene bags of a recalcitrant species (Quercus ilex): analysis of some bio-nergetic and oxidative parameters. Acta Physiologiae Plantarum 2012; 34(5):1963-1974.

$\mathrm{R}$ Core Team. R: A language and environment for statistical computing. R Foundation for Statistical Computing, Vienna, Austria. 2020. URL https://www.R-project.org/.

Vicente D, Oliveira LM, Tonetti OAO, Silva AA, Liesch PP, Engel ML. Viabilidade de sementes de Ocotea puberula (Rich.) Ness ao longo do armazenamento. Floresta e Ambiente 2016; 23(3):418-426.

Walters C. Levels of recalcitrance in seeds. Revista Brasileira de Fisiologia Vegetal 2000; 12(1):7-21.

Walters C, Hill LM, Wheeler LJ. Dying while dry: kinetics and mechanisms of deterioration in desiccated organisms. Integrative and Comparative Biology 2005; 45(5):751-758.

Walters C, Pammenter NW, Berjak P, Crane J. Desiccation damage, accelerated ageing and respiration in desiccation tolerant and sensitive seeds. Seed Science Research 2001; 11(2):135-148. 